\title{
KONSTYTUCYJNE RAMY KADENCYJNOŚCI ORGANÓW WLADZY PUBLICZNEJ
}

I. Praktyka nadawania organom państwa charakteru kadencyjnego jest znana w ustawodawstwie od dosyć dawna. Jej geneza wiąże się z problemem walki z naturalną tendencją absolutyzacji władzy, gdyż ma utrudniać jej monopolizację ${ }^{1}$. W tym celu dąży się do tego, aby tworzyć prawne możliwości zastępowania jednych piastunów władzy innymi - nie tylko w razie śmierci lub wystapienia biologicznej okoliczności zmuszającej do odebrania mandatu, lecz także przez ustalenie z góry odpowiedniego okresu wykonywania funkcji. Po upływie tego terminu wybrany przedstawiciel przestaje być legitymowany do dalszego sprawowania władzy i powraca niejako w szeregi zwykłych członków danej społeczności. W doktrynie trafnie wskazuje się, że zmniejsza to ryzyko nadużywania przez decydentów swojej pozycji, gdyż w ramach swoistej sankcji za niewłaściwe zachowanie ich mandat może nie zostać odnowiony ${ }^{2}$. Może towarzyszyć im ponadto obawa, że szkodliwe działania, które podejmują w ramach swojej kadencji, obróca się przeciwko nim samym, gdy tylko będa kontynuowane w kolejnej kadencji przez nowych reprezentantów danej społeczności ${ }^{3}$ W tym sensie czasowe limitowanie sprawowania władzy może być postrzegane jako pośrednia forma realizacji odpowiedzialności politycznej osób kierujacych państwem przed wybierającymi ich obywatelami ${ }^{4}$.

Współcześnie zagadnienie kadencyjności jest nierozerwalnie sprzężone $\mathrm{z}$ zasada demokratyzmu oraz wynikajaca $\mathrm{z}$ niej zasada wybieralności. Instytucja kadencji stanowi oczywisty składnik ustroju demokratycznego (republikańskiego), w którym rządzący kontrolowani są przez naród za pomoca regularnie przeprowadzanych wyborów. Periodyczność wyborów oznacza zaś dokonywanie wyboru tylko na pewien okres, z którego końcem następuje ponowna weryfikacja kandydatów do objęcia państwowych stanowisk ${ }^{5}$. W konsekwencji demokratyczne wybory nie tylko legitymizuja władzę w danym przedziale czasowym, ale zarazem nadaja jej charakter „odwracalny”, powodując cykliczną wymianę elit politycznych. W państwie prawnym (praworządnym) w idei kadencji - poza ograniczeniem temporalnym - mieści się dodatkowo ograniczenie zakresu swobody działania organu, gdyż władza przedstawicieli

\footnotetext{
${ }^{1}$ Ławniczak, Masternak-Kubiak (2002): 9.

2 Ławniczak, Masternak-Kubiak (2002): 9.

${ }^{3}$ Korczak (2014): 38.

${ }^{4}$ Magiera (2018): 1253.

${ }^{5}$ Por. używane w niemieckiej doktrynie pojęcie Herrschaft (Herrschaftsgewalt) nur auf Zeit.

${ }^{6}$ Hofmann, Dreier (1989): 178-179.
} 
narodu może być realizowana wyłącznie w ramach upoważnień udzielonych im przez przepisy prawa oraz w formach prawem przewidzianych.

Trzeba od razu zaznaczyć, że zasada kadencyjności nie ma identycznego przełożenia na wszystkie segmenty podzielonej władzy państwowej. Ewidentnie mniejszą przydatność wykazuje przede wszystkim w ramach władzy sądowniczej, z której niezależnością - jak zwykło się uważać - lepiej współgra mechanizm powoływania na czas nieoznaczony ${ }^{7}$. Odstapienie w obszarze sądownictwa od bezpośredniej legitymacji demokratycznej uzasadnione jest również silną profesjonalizacją zawodu sędziego oraz koniecznościa posiadania przez osoby ubiegajace się o ten urząd odpowiednich predyspozycji i wysokich wymagań kwalifikacyjnych, które nie podlegają prostej weryfikacji wyborczej. Taki sposób legitymizacji osób sprawujących władzę sądzenia dąży do zachowania wymagań płynących z fachowości - niezależnych od swobodnego uznania grupy ${ }^{8}$. Co więcej, w piśmiennictwie podnosi się, że pojęcie kadencyjności ma ograniczone zastosowanie w procesie obsady stanowisk w ramach takich struktur organizacyjnych, jak sądy czy trybunały obrachunkowe (izby kontroli). W ramach tego typu ciał na okres kadencji powołuje się co najwyżej wybrane organy wewnętrzne, w szczególności sądowe organy kierownicze ${ }^{9}$.

II. W nauce prawa konstytucyjnego kadencję organu definiuje się na ogół jako: „okres jego pełnomocnictw, a więc okres, na jaki dany organ jest powoływany i w jakim może sprawować swoje funkcje w określonym składzie”10. Od dawna podobnie rozumiana jest zasada kadencyjności w orzecznictwie Trybunału Konstytucyjnego, w którym za podstawową jej cechę uznaje się „nadanie pełnomocnictwom danego organu z góry oznaczonych ram czasowych” połączone z utrzymaniem „Stabilizacji składu personalnego tego organu w ramach kadencji" ${ }^{11}$. Wypowiedzi te dobrze oddają teoretycznoprawny sens kadencyjności. Można mieć tylko pewne wątpliwości, czy zasadne (i potrzebne) jest odnoszenie wywodzącej się z prawa prywatnego - i tam też ugruntowanej - konstrukcji pełnomocnictwa do stosunku ustrojowoprawnego, jaki powstaje między osobą pełniącą funkcję kadencyjną a podmiotem ją na tę funkcję nominującym.

Pełnomocnictwo w ujęciu cywilistycznym jest instytucją fakultatywną (dobrowolna) i w konsekwencji może być co do zasady przez mocodawcę w każdym czasie odwołane (art. $101 \S 1$ ustawy z 23 kwietnia 1964 r. - Kodeks cywil$n y^{12}$ ) - i to bez zachowania formy szczególnej, nawet jeśli jest ona zastrzeżona dla jego udzielenia ${ }^{13}$. Zupełnie nie przystaje to do umocowania występującego

${ }^{7}$ Zob. Brzozowski (2016): 175-182.

${ }^{8}$ Zob. Zubik (2018): 69-70.

${ }^{9}$ Ławniczak, Masternak-Kubiak (2002): 10; Brzozowski (2016): $116 \mathrm{n}$.

${ }^{10}$ Siemieński (1980): 263. Stosunkowo podobnie Gwiżdż (1975): 268.

11 Tak już orzeczenie TK z 23 kwietnia 1996 r., K 29/95, OTK 1996, nr 2, poz. 10, cytowane wielokrotnie w późniejszym orzecznictwie, m.in. w wyroku TK z 15 lipca 2009 r., K 64/07, OTK-A 2009, nr 7, poz. 110.

${ }^{12}$ Dz. U. 2019, poz. 1145 ze zm.

${ }^{13}$ Zob. np. wyrok SN z 4 listopada 1998 r., II CKN 866/97, OSNC 1999, nr 3, poz. 66. 
w prawie publicznym, w którym stanowi ono konieczny (obligatoryjny) składnik demokracji przedstawicielskiej oraz może być cofnięte tylko w sytuacjach ściśle określonych przepisami prawa i przy zachowaniu wszystkich wymagań proceduralnych. Posługiwanie się kategoria pełnomocnictwa w stosunku do kadencji organu władzy publicznej jest zatem uzasadnione tylko przy zastrzeżeniu, że rozumie się ją autonomicznie i używa na oznaczenie powierzenia danej osobie obowiązków władczych o sztywno określonym zakresie ${ }^{14}$. W tym też znaczeniu kategoria ta będzie występowała w dalszych rozważaniach.

Z przytoczonej definicji kadencji organu wynika, iż na treść zasady kadencyjności składają się dwa podstawowe elementy. Istnienie obu tych elementów jest konieczne, aby można było mówić o kadencji, ale w zależności od konkretnych regulacji prawnych różny może być stopień intensywności ich występowania. Oba te założenia składają się łącznie na zasadę, która podlega relatywizacji w schemacie „więcej lub mniej”. Pierwszy - instytucjonalny - element zasady kadencyjności wyraża się w ustanowieniu pewnego górnego horyzontu czasowego urzędowania danego organu lub jego członka, przy czym musi być on znany a priori, jeszcze przed rozpoczęciem funkcjonowania podmiotu w danej kadencji. Granica długości kadencji zakreślona jest tu w wymiarze maks y ma lny m${ }^{15}$, stąd też obok kadencji „normalnej” w szczególnych przypadkach może występować kadencja „skrócona” lub organ może zakończyć swoją działalność przed upływem kadencji.

Drugi - personalny - aspekt zasady kadencyjności przejawia się w zapewnieniu określonego poziomu stabilizacji składu osobowego organu w okresie trwania pełnomocnictw. Z tej perspektywy konstrukcja kadencji tworzy pewne $\mathrm{m}$ i $\mathrm{n}$ i $\mathrm{m} \mathrm{u} \mathrm{m}$ o walorze gwarancyjnym, gdyż ustalenie czasowych ram kadencji ma chronić trwałość funkcjonowania danej osoby (zespołu osób) w charakterze organu. Co oczywiste, nie oznacza to jednak absolutnej niezmienności obsady personalnej organu w trakcie całej kadencji, gdyż prawo musi regulować sytuacje, w których kontynuowanie mandatu przez jego piastunów (pojedynczych lub wszystkich łącznie) jest niepożądane bądź wręcz niemożliwe. Wynika to już choćby tylko z uwzględnienia biologicznych uwarunkowań ludzkiego życia ${ }^{16}$.

Skrajnym przykładem odejścia od myślenia o kadencyjności w kategoriach dogmatycznych jest anglosaska koncepcja kadencji elastycznej, w której kosztem stabilności substratu osobowego organu występuje większa swoboda $\mathrm{w}$ jego kreowaniu. W prawie kontynentalnym przeważa raczej sztywny model kadencyjności, dlatego uważa się, że wszelkie odstępstwa od pełnego okresu kadencji musza być oparte na wyraźnej podstawie prawnej, a także powinny mieć charakter wyjątkowy oraz znajdować uzasadnienie w świetle zasad, norm i wartości konstytucyjnych ${ }^{17}$.

${ }^{14}$ Por. Jastrzębski, Zubik (2007): 68.

${ }^{15}$ Por. Versteyl (1989): 472.

${ }^{16}$ Grajewski (2009): 193.

17 Brzozowski (2016): 184. Niektórzy autorzy piszą w tym kontekście o „względnej elastyczności długości trwania kadencji” - tak Ławniczak, Masternak-Kubiak (2002): 13. 
III. Z omówionymi wyżej warunkami brzegowymi zasady kadencyjności wiążą się jej podstawowe funkcje. Po pierwsze, w związku z czasowym ograniczeniem funkcjonowania organu zapewnia ona periodyczna wymianę jego piastunów. Powoduje tym samym stały dopływ „świeżej krwi” i zapobiegając mentalnemu zastojowi, nadaje coraz to nowe impulsy do prowadzenia szeroko rozumianej polityki państwa. W przypadku organów wyłanianych w wyborach powszechnych rotacja składu osobowego sprawia, że ich reprezentacja odzwierciedla aktualną wolę elektoratu, uzewnętrznianą w okresowo organizowanych wyborach, które odnawiają demokratyczną legitymację poszczególnych członków. Przeciwieństwem kadencyjności jest powołanie organu na czas nieokreślony, co nie sprzyja trosce jego piastunów o społeczne poparcie dla podejmowanych przez nich działań. Po drugie, czynnik stabilizacji personalnej umożliwia swobodne, nieskrępowane i niezależne wykonywanie zadań organu $\mathrm{w}$ ramach kadencji ${ }^{18}$.

Stopień urzeczywistnienia obu tych funkcji może być różny w zależności od charakterystyki organu oraz roli, jaka pełni w systemie prawa. W literaturze zwraca się uwagę, że z przewaga znaczenia jednej funkcji nad druga koresponduje przyjęty czas trwania kadencji. Nie musi być on określony liczbowo, lecz wystarczy już samo wskazanie pozwalające ex ante ustalić górny limit czasowy misji danego organu. Wydaje się, że prymat funkcji rotacyjnej nad stabilizacyjna skłania do projektowania kadencji krótkiej, a większe znaczenie trwałości pełnomocnictw nad wymiana składu sugeruje posłużenie się kadencją długą ${ }^{19}$. Określenia te sa, rzecz jasna, umowne, gdyż nie istnieje jednolity standard w zakresie wymiaru kadencji poszczególnych organów. Odstępy czasowe pomiędzy kolejnymi aktami wyboru mandatariuszy powinny być adekwatne, tj. ani zbyt krótkie, ani zbyt długie. Powinny być regulowane $\mathrm{w}$ rozsąnych granicach, wyznaczanych $\mathrm{z}$ jednej strony przez zasadę sprawności działania władz publicznych, a z drugiej - przez względy efektywności kontroli demokratycznej dokonywanej przez wybory (choćby nawet miały one charakter wyborów pośrednich ${ }^{20}$. Na przykład w odniesieniu do kadencji parlamentarnej zwykło się przyjmować, że długość mieszcząca się w przedziale od 3 do 5 lat odpowiada konstytucyjnym potrzebom zwierzchnictwa narodu nad jego reprezentantami ${ }^{21}$.

IV. Ukształtowanie danego organu jako kadencyjnego może wynikać z przepisów rangi konstytucyjnej lub ustawowej. Pomijam w tym miejscu organy kreowane jako kadencyjne w prawie prywatnym, które dopuszcza określanie kadencji także w drodze aktów normatywnych niższej rangi, a nawet w wyniku czynności prawnych, takich jak statut (w przypadku stowarzyszeń i fundacji) bądź umowa lub statut (w przypadku niektórych spółek prawa handlowego). W każdym razie kadencyjność w prawie publicznym musi zawsze

\footnotetext{
18 Zob. Zubik (2005): 40-41.

19 Brzozowski (2016): 186.

20 Por. Kretschmer (2009): 30-31; Morlok (2015): 1138-1139; Schliesky (2018): 1102-1103.

21 Tak w niemieckiej doktrynie np. Schneider (1989): 64.
} 
wynikać z normy o charakterze generalnym i abstrakcyjnym, określającej jednolicie okres urzędowania organu w ramach następujących po sobie kadencji.

Trzeba podkreślić, że źródło regulacji ma w przypadku kadencyjności organów państwa kluczowe znaczenie, gdyż determinuje jej prawny charakter. Wydaje się, że o kadencyjności rzeczywistej - a nie tylko iluzorycznej czy deklaratywnej - można mówić jedynie w stosunku do organów, których kadencyjny status zakotwiczony jest konstytucyjnie ${ }^{22}$. Nie musi być to wyraźne unormowanie, określające precyzyjnie czasowy wymiar sprawowania pełnomocnictw, lecz muszą istnieć przynajmniej przesłanki świadczace o zamiarze ustrojodawcy nadania organowi charakteru kadencyjnego - a właściwie raczej brak przesłanek wskazujących na odmienna jego intencję. Wolno bowiem, zaryzykować tezę, iż wszędzie tam, gdzie Konstytucja Rzeczypospolitej Polskiej z 2 kwietnia $1997 \mathrm{r}^{23}$ wprost nie odmawia osobie pełniącej urząd statusu kadencyjnego lub posługuje się konstrukcją nominacji na czas nieoznaczony (jak np. w art. 179), należy generalnie przyjmować ograniczony czasowo zakres wykonywania pełnomocnictw.

Nawet w przypadku tych organów, których kadencja została w Konstytucji pominięta legislacyjnym milczeniem ${ }^{24}$, należałoby chyba domniemywać ich obligatoryjnie kadencyjny charakter - niemający oczywiście podstawy $\mathrm{w}$ Konstytucji, lecz kształtowany z jej upoważnienia (tj. w istocie nakazu) w drodze ustawy. Jedna z dyrektyw nom ustrojowych jest bowiem przecież zapobieganie tendencji do kumulacji funkcji władczych oraz wymuszanie okresowej aktualizacji poparcia dla osób piastujących stanowiska publiczne. Stopień konstytucjonalizacji kadencji organu (zakres jej doregulowania na szczeblu konstytucyjnym) będzie przesądzał natomiast co najwyżej o zakresie nienaruszalności jej poszczególnych elementów w ramach konstytucyjnej ochrony przed ewentualnymi próbami ich przełamania przez ustawodawcę zwykłego. Tylko bezpośrednie umocowanie kadencyjności na poziomie ustawy zasadniczej gwarantuje trwałe zachowanie (utrzymanie) tej cechy na przyszłość, uniemożliwiając całkowite jej zniesienie w wyniku woli politycznej zwykłej większości parlamentarnej ${ }^{25}$.

V. W polskim systemie prawnym funkcjonuje wiele organów kadencyjnych, które wywodzą ten czynnik swojego statusu tylko z ustawy. Tytułem przykładu można tu choćby wskazać Prezesa Urzędu Regulacji Energetyki, Kolegium Instytutu Pamięci Narodowej - Komisji Ścigania Zbrodni przeciwko Narodowi Polskiemu czy Rzecznika Małych i Średnich Przedsiębiorców ${ }^{26}$. Ustawowe zadekretowanie zasady kadencyjności ma dla tych organów bar-

${ }^{22}$ Por. Brzozowski (2016): 11.

${ }^{23}$ Dz. U. Nr 78, poz. 483 ze zm. (dalej jako: Konstytucja).

${ }^{24}$ Zob. np. lakoniczną regulację dotyczącą Rzecznika Praw Dziecka zawartą w art. 72 ust. 4 Konstytucji.

${ }_{25}$ Por. Skrzydło (1997): 15-16.

${ }^{26}$ Zob. odpowiednio art. 21 ust. 21 ustawy z 10 kwietnia 1997 r. - Prawo energetyczne (Dz. U. 2019, poz. 755 ze zm.); art. 15 ust. 8 ustawy z 18 grudnia 1998 r. o Instytucie Pamięci Narodowej - Komisji Ścigania Zbrodni przeciwko Narodowi Polskiemu (Dz. U. 2019, poz. 1882); art. 4 ust. 1 ustawy z 6 marca 2018 r. o Rzeczniku Małych i Średnich Przedsiębiorców (Dz. U. poz. 648). 
dzo ograniczone konsekwencje normatywne, gdyż w każdym czasie możliwe jest zakończenie ich misji w drodze ustawy zwykłej. Obejmuje to w pierwszej kolejności te organy, których sam byt prawny proklamowany został również wyłącznie na szczeblu ustawodawstwa zwykłego. Prawodawca jest wówczas władny doprowadzić do ich całkowitego usunięcia (zlikwidowania), a więc tym bardziej może przerwać ich kadencję wcześniej, niż wynikałoby to ze zwykłego biegu spraw ${ }^{27}$.

W dotychczasowym orzecznictwie konstytucyjnym wypracowano jednak pewien minimalny standard, jaki powinna spełniać każda norma ustawowa dotycząca kadencyjności organu. Próbując ustalić treść zasady kadencyjności, w jednym ze swoich wyroków Trybunał Konstytucyjny stwierdził, że oznacza ona, po pierwsze, nakaz nadania pełnomocnictwom danego organu z góry oznaczonych ram czasowych, po drugie, nakaz ukształtowania owych ram czasowych w taki sposób, aby nie przekroczyły pewnych rozsądnych granic, oraz po trzecie, nakaz ustanowienia regulacji prawnych, które zapewnią ukonstytuowanie się nowo wybranego organu w sposób umożliwiający mu rozpoczęcie wykonywania jego funkcji bez nadmiernej zwłoki, po zakończeniu poprzedniej kadencji ${ }^{28}$.

Zdaniem Trybunału spełnienie pierwszego z warunków może nastapić w różny sposób - zależnie od metody wybranej przez ustawodawcę. Może on określić długość kadencji poprzez sztywne i jednoznaczne wskazanie dnia jej zakończenia bądź też uzależnić ten moment od określonych zdarzeń prawnych, wyznaczając wówczas precyzyjnie pewien wąski przedział czasowy, w którym musi nastąpić upływ kadencji. Bez względu na przyjęte rozwiązanie konieczne jest dokładne wyznaczenie horyzontu czasowego kadencji danego organu, tak aby okres kadencji był znany jeszcze przed wyborem danego organu i nie był zmieniany w odniesieniu do organu już wybranego. Ewentualne zmiany długości kadencji powinny wywoływać skutki pro futuro - w odniesieniu do organów, które zostaną wybrane dopiero w przyszłości ${ }^{29}$.

Zasada kadencyjności nie wyklucza, według Trybunału, wprowadzenia regulacji prawnych umożliwiajacych skrócenie kadencji. Regulacje prawne określające zasady skrócenia kadencji powinny być ustanowione przed rozpoczęciem kadencji i nie powinny w zasadzie być zmieniane w odniesieniu do organu już urzędującego. Jedynie w szczególnych sytuacjach Trybunał dopuszcza zmianę obowiązującej regulacji i skrócenie kadencji organu, pomimo że prawo pierwotnie w ogóle tego nie przewidywało lub też określało przesłanki skrócenia kadencji w sposób bardziej restryktywny. Takie rozwiązanie jest dopuszczalne wyłącznie pod warunkiem, że przemawiają za tym szczególne

${ }^{27} \mathrm{~W}$ świetle utrwalonej linii orzeczniczej TK takie działanie ustawodawcy nie stoi w sprzeczności z konstrukcją praw nabytych, gdyż dotyczy ona wyłącznie sytuacji, gdy adresatem nowych uregulowań jest obywatel występujący jako indywidualny uczestnik obrotu prawnego. Piastowanie funkcji publicznej w ramach całego okresu kadencji organu nie jest słusznie nabytym prawem podmiotowym, a więc nie korzysta w tym zakresie z ochrony wynikającej z art. 2 Konstytucji zob. m.in. wyrok TK z 23 marca 2006 r., K 4/06, OTK-A 2006, nr 3, poz. 32 wraz z przytoczonymi tam wcześniejszymi orzeczeniami.

${ }^{28}$ Wyrok TK z 26 maja 1998 r., K 17/98, OTK 1998, nr 4, poz. 48.

${ }^{29}$ Wyrok TK z 26 maja 1998 r., K 17/98. 
okoliczności, a szczegółowy przepis konstytucyjny tego nie zakazuje. Wymaga to zawsze ustanowienia odpowiedniego aktu prawodawczego, zmieniajacego wcześniej obowiąujące przepisy określające ramy czasowe działania organu ${ }^{30}$.

Z istoty kadencyjności wynika tym bardziej, że kadencja organu nie powinna być przedłużana w odniesieniu do organu urzędującego. Obywatele, wybierając określony organ, udzielają mu bowiem jednocześnie pełnomocnictw o określonej przez prawo treści i określonym czasie ważności. Upływ tego czasu oznacza wygaśnięcie pełnomocnictwa i utratę legitymacji do sprawowania władzy. Kategoryczny zakaz przedłużenia kadencji dotyczy przede wszystkim naczelnych organów państwa, których kadencja została wyraźnie określona konstytucyjnie - jedyny wyjątek stanowi tu art. 228 ust. 7 Konstytucji, mający zastosowanie w sytuacjach szczególnych (nieprzewidywalnych) ${ }^{31}$.

Z obowiązkiem wyznaczenia czasu pełnomocnictw danego organu za pomoca kadencji wiąże się nakaz stabilizacji (ochrony) jego substratu osobowego w okresie trwania tych pełnomocnictw. Dotyczy to w szczególności organów, których wybór dokonywany jest bezpośrednio przez wyborców, ponieważ ogólne konsekwencje zasady kadencyjności splatają się wówczas z obowiązkiem szanowania woli wyborców wyrażonej w demokratycznym akcie głosowania ${ }^{32}$. Sytuacje, w których skład personalny organu wybieralnego (kadencyjnego) ulega zmianom w okresie kadencji, należy traktować jako wyjątki, dopuszczalne pod warunkiem, że ingerencja w kadencyjność nie następuje w sposób nadmierny, niewspółmierny do innych wartości konstytucyjnie chronionych, takich jak ważny interes publiczny ${ }^{33}$. Z zasady kadencyjności nie wynika jednak nakaz stabilizacji układu kompetencyjnego organów wybieralnych w trakcie trwania kadencji, a dokonanie przez ustawodawcę korekty zakresu kompetencji danego organu w czasie sprawowania przez ten organ funkcji nie oznacza automatycznie jego delegitymizacji przed upływem kadencji ${ }^{34}$.

Drugim elementem zasady kadencyjności jest wymaganie, by ustalone ramy czasowe działania organu nie przekraczały „pewnych rozsadnych granic" 35 . Ze swej istoty element ten ma zastosowanie praktyczne tylko wówczas, gdy Konstytucja zastrzega w stosunku do danego organu, że ma on charakter kadencyjny, a jednocześnie pozostawia ustawodawcy swobodę co do określenia długości kadencji. Z taką konstrukcja mamy do czynienia między innymi w przypadku organów jednostek samorządu terytorialnego ${ }^{36}$. Co jednak istotne, ustawodawca nie ma pełnego luzu w ustalaniu tego okresu, zwłaszcza w stosunku do organów stanowiących, których wybór zdeterminowany jest

30 Wyrok TK z 26 maja 1998 r., K 17/98.

31 Wyrok TK z 26 maja 1998 r., K 17/98.

32 Orzeczenie TK z 23 kwietnia 1996 r., K 29/95.

33 Wyrok TK z 31 marca 1998 r., K 24/97, OTK 1998, nr 2, poz. 13.

34 Wyrok TK z 3 listopada 1999 r., K 13/99, OTK 1999, nr 7, poz. 155.

35 Por. także treść prawa do wolnych wyborów wyrażonego w art. 3 Protokołu nr 1 do Konwencji o ochronie praw człowieka i podstawowych wolności, sporządzonego w Paryżu 20 marca 1952 r. (Dz. U. 1995, Nr 36, poz. 175).

36 Brzozowski (2016): 183. 
konstytucyjnie (w art. 169 ust. 2) czteroprzymiotnikowym prawem wyborczym, z zasadą powszechności na czele. Wynika stąd, że kolejne wybory powinny być przeprowadzane w rozsądnych odstępach czasu, tak aby umożliwić wyborcom udział w kierowaniu sprawami swojej wspólnoty samorządowej oraz aby skład organów stanowiących nie odbiegał nadmiernie od aktualnej woli elektoratu, która może ulegać zmianom w toku kadencji ${ }^{37}$.

Trzecie wymaganie zasady kadencyjności, dotyczące ustanowienia regulacji prawnych zapewniających płynne ukonstytuowanie się i rozpoczęcie działania przez nowo wybrany organ, jest $\mathrm{w}$ istocie warunkiem poprawnej legislacji wyborczej. Jego spełnienie zależy od zasad organizacji trybu wyboru, których celem powinno być utrzymanie ciagłości działania konstytucyjnych organów państwa $^{38}$. Zdaniem Trybunału, nie oznacza to, że między zakończeniem jednej kadencji a rozpoczęciem kolejnej nie może upłynać pewien czas. Nie jest możliwe ustalenie in abstracto maksymalnej długości dopuszczalnej przerwy międzykadencyjnej następującej po upływie kadencji danego organu. Pewne jest, że nie może ona przekroczyć właściwej granicy, którą wyznacza czas potrzebny do przygotowania procesu wyborczego (kreacyjnego). W przypadku organów wybieranych $\mathrm{w}$ wyborach powszechnych prawo nie reguluje $\mathrm{z}$ reguły w sposób sztywny długości przerwy międzykadencyjnej, pozostawiając organowi zarządzającemu wybory pewną swobodę przy wyborze dnia głosowania, w określonym przedziale czasowym. Niemniej jej maksymalny okres, podobnie jak długość kadencji, powinien być w zasadzie ustalony już w momencie wyboru tego organu, tak aby wyborcy z góry znali termin kolejnych wyborów ${ }^{39}$.

VI. Zasady kadencyjności niemającej podstawy w Konstytucji nie można porównywać z zasadą kadencyjności organów, w stosunku do których została ona ugruntowana konstytucyjnie ${ }^{40}$. Tylko bowiem w tym drugim przypadku czas funkcjonowania $\mathrm{w}$ ramach kadencji zabezpieczony został mechanizmem prawnym o wysokim stopniu trwałości, którego zmiana wymaga sprostania sztywnym wymogom proceduralnym związanym ze zmianą Konstytucji w trybie art. $235^{41}$. Konstytucja określa szczegółowo kadencje wielu organów, m.in. Sejmu i Senatu (art. 98 ust. 1), Prezydenta Rzeczypospolitej Polskiej (art. 127 ust. 2) czy Pierwszego Prezesa Sądu Najwyższego (art. 183 ust. 3) ${ }^{42}$. Niejako pośredni charakter ma natomiast

${ }^{37}$ Wyrok TK z 26 maja 1998 r., K 17/98.

${ }^{38}$ Por. następujacy passus z późniejszego chronologicznie wyroku TK z 23 marca 2006 r., K 4/06: „wszelkie wyjątki od zasady ciagłości działania organów konstytucyjnych stanowią zagrożenie dla realizacji konstytucyjnych funkcji państwa".

${ }^{39}$ Wyrok TK z 26 maja 1998 r., K 17/98.

${ }^{40}$ Wyrok TK z 1 lipca 2008 r., K 23/07, OTK-A 2008, nr 6, poz. 100.

${ }^{41}$ Por. Brzozowski (2016): 12.

${ }^{42} \mathrm{Z}$ tego punktu widzenia konstytucyjnie wattpliwy był mechanizm zawarty w art. $12 \S 1$ zd. drugie w związku z art. $111 \S 1$ zd. pierwsze ustawy z 8 grudnia 2017 r. o Sądzie Najwyższym (Dz. U. 2019, poz. 825 ze zm.) w brzmieniu obowiązującym przed zmiana dokonaną ustawa z 21 listopada 2018 r. o zmianie ustawy o Sądzie Najwyższym (Dz. U. poz. 2507), na mocy której uchylono art. $111 \S 1$. Mechanizm ten prowadził do ustawowego przerwania kadencji ówczesnego Pierwszego Prezesa Sądu Najwyższego na podstawie przepisów obniżających wiek przejścia 
zasada kadencyjności Szefa Sztabu Generalnego i dowódców rodzajów Sił Zbrojnych (oraz wspominanych już organów jednostek samorządu terytorialnego), jak również Krajowej Rady Radiofonii i Telewizji. W przypadku tych pierwszych osób Konstytucja ustanawia w art. 134 ust. 3 wymóg mianowania ich na czas oznaczony, ale określenie czasu trwania kadencji pozostawia zarazem ustawodawcy zwykłemu. Stosunkowo bardziej skomplikowany jest casus Krajowej Rady Radiofonii i Telewizji, gdyż teoretycznie brzmienie art. 214 ust. 1 Konstytucji nie daje nawet podstaw do twierdzenia, że organ ten musi mieć charakter kadencyjny, aczkolwiek taki właśnie wydaje się sens zawartej $\mathrm{w}$ tym artykule regulacji ${ }^{43}$.

O tym, jak istotne znaczenie twórcy ustawy zasadniczej przypisywali zasadzie kadencyjności organów władzy publicznej, przekonuje lektura art. 238 Konstytucji. Przepis ten szczegółowo określa skutki wejścia w życie Konstytucji dla biegu kadencji organów i osób wchodzących w ich skład, wybranych lub powołanych przed wejściem w życie Konstytucji. Ustanowiony na mocy art. 238 Konstytucji mechanizm kontynuacji funkcjonowania organów władzy publicznej ma co prawda charakter przejściowy i z uwagi na upływ czasu zakres jego zastosowania uległ już wyczerpaniu, ale wciąż pokazuje silne przywiązanie ustawodawcy konstytucyjnego do stworzenia zasadniczych gwarancji stabilizacji obsady personalnej organów konstytucyjnych w okresie trwania kadencji.

VII. Dążenie ustrojodawcy zmierzające do ekstensywnego uregulowania kadencyjnego charakteru organów konstytucyjnych przejawia się w wielu przepisach Konstytucji poświęconych kadencji poszczególnych organów państwa. Bliższa analiza konkretnych rozwiązań konstytucyjnych prowadzi do wniosku, że nie zostały one ukształtowane według jednego schematu ${ }^{44}$. Pewna niekonsekwencja w sposobie określania kadencyjności widoczna jest przede wszystkim w stosunku do organów o złożonej strukturze osobowej. W świetle ustaleń nauki prawa można je przyporządkować jednemu z dwóch następujących modeli ${ }^{45}$.

w stan spoczynku sędziów Sądu Najwyższego - szerzej na ten temat zob. Grajewski (2018): 609 n.; Radajewski (2019): 288-291. Z kolei jeszcze więcej zastrzeżeń konstytucyjnych nasuwa art. 6 ustawy z 8 grudnia 2017 r. o zmianie ustawy o Krajowej Radzie Sądownictwa oraz niektórych innych ustaw (Dz. U. 2018, poz. 3), za pomocą którego wygaszono mandaty sędziów zasiadających dotąd w Krajowej Radzie Sądownictwa. Ten ostatni zabieg podyktowany był wykonaniem wyroku TK z 20 czerwca 2017 r., K 5/17, OTK-A 2017, poz. 48, którego ważność jest jednak powszechnie podważana w środowisku prawniczym - zob. Radajewski (2018): 132-133; Łukowiak (2018): 63-64; ostatnio także wyrok SN z 5 grudnia 2019 r., III PO 7/18, niepubl.

${ }^{43}$ Skape unormowanie konstytucyjne zwiększa z jednej strony swobodę regulacyjną ustawodawcy w tym zakresie (art. 215 Konstytucji), ale z drugiej - nie może oznaczać zgody na działania ustawodawcze zmierzające do przerwania ciagłości funkcjonowania tego organu, a takie znamiona nosiło wygaszenie w drodze ustawy dotychczasowej kadencji wszystkich członków Rady - zob. wyrok TK z 23 marca 2006 r., K 4/06.

${ }^{44}$ Stąd też słusznie wysuwa się postulat stworzenia kompleksowej i spójnej regulacji konstytucyjnej w tym zakresie - zob. Brzozowski (2017): 16-17.

${ }^{45}$ Zob. Zubik (2005): 41-42; Korczak (2014): 39-40. Przedstawianemu dalej dychotomicznemu podziałowi kadencyjności polskich organów konstytucyjnych wymyka się jednak Krajowa 
W pierwszym z nich prawo ustala kadencję jednolicie w odniesieniu do całego składu organu (model kadencji zbiorowej). Oznacza to, że wszystkim członkom organu upłynie ona w tym samym czasie, a ewentualne wcześniejsze opróżnienie miejsca będzie skutkowało dokonaniem wyboru uzupełniającego jedynie na okres pozostały do końca kadencji. Taka konstrukcja przewidziana została w stosunku do Sejmu i Senatu, które wybierane sa na czteroletnie kadencje (art. 98 ust. 1 zd. pierwsze Konstytucji), Rady Ministrów, skoro dymisja Prezesa Rady Ministrów, składana obligatoryjnie na pierwszym posiedzeniu nowo wybranego Sejmu, kończy misję całego rządu (art. 162 ust. 1 Konstytucji), oraz Trybunału Stanu, którego członkowie wybierani są przez Sejm na czas jego kadencji (art. 199 ust. 1 zd. pierwsze Konstytucji).

Drugi model zakłada indywidualizację sytuacji prawnej członków organu kolegialnego i przypisanie każdemu z nich własnej (odrębnej) kadencji, która liczona jest zwykle od dnia wyboru, powołania, mianowania czy innej formy powierzenia funkcji publicznej. W tym przypadku członkostwo w organie wygasa poszczególnym osobom $\mathrm{w}$ różnym czasie i nie ma potrzeby określania odrębnego trybu postępowania $\mathrm{w}$ sprawie uzupełnienia obsady personalnej organu, gdyż odbywa się to zawsze na zasadach ogólnych i na pełny okres kadencji. Taką konstrukcję projektuje Konstytucja niewątpliwie w odniesieniu do TK, którego sędziowie, zgodnie z wyraźnym brzmieniem art. 194 ust. 1 zd. pierwsze Konstytucji, wybierani są indywidualnie przez Sejm na dziewięcioletnie kadencje. Trybunał Konstytucyjny nie ma charakteru kadencyjnego in gremio, lecz kadencyjny jest urząd każdego z jego 15 sędziów. Podobnie, choć w mniej oczywisty sposób, kwestia ta uregulowana została w stosunku do członków Rady Polityki Pieniężnej, z których każdy - włącznie z Prezesem Narodowego Banku Polskiego jako jej przewodniczacym - powoływany jest odrębnie na okres 6 lat (art. 227 ust. 3 i 5 Konstytucji) ${ }^{46}$.

Rozwiązanie mieszane występuje natomiast $\mathrm{w}$ typie tzw. kadencji kroczącej, która polega na tym, że kadencyjność dotyczy nie pojedynczych członków organu, lecz grup lub kategorii członków, podlegających okresowej rotacji ${ }^{47}$. $\mathrm{Z}$ jednej strony jest ona więc bliska logice kadencji indywidualnej, gdyż występuje tu wewnętrzne zróżnicowanie biegu kadencji osób wchodzących w skład organu; z drugiej - upodabnia się do schematu kadencji wspólnej, ponieważ czas trwania kadencji wszystkich członków jest jednolity, a wymiana składu następuje grupowo i w ramach tych grup kadencja upływa w sposób łączny. Polska Konstytucja nie zna takiego modelu określania kadencyjności, na szczeblu ustawowym jednak obowiązywał on kiedyś między innymi w odniesieniu do Trybunału Konstytucyjnego oraz Rady Służby Publicznej (ówcześnie Rady

Rada Sądownictwa, której status został z tej perspektywy skonstruowany w Konstytucji w sposób mocno zniuansowany. Omówienie tego problemu wykracza poza ramy niniejszego tekstu, ale był on już podejmowany w literaturze, m.in. w związku z błędnym wyrokiem TK z 20 czerwca 2017 r., K 5/17 - z nowszych opracowań zob. zwłaszcza Brzozowski (2016): 189-191; Radajewski (2018): 136-138; Łukowiak (2018): $63 \mathrm{n}$.

${ }^{46}$ Kwestia ta wywołała w swoim czasie wiele kontrowersji, które ostatecznie przecią wyrok TK z 24 listopada 2003 r., K 26/03, OTK-A 2003, nr 9, poz. 95. Zob. również szerzej Zubik (2010): 1423-1424.

${ }^{47}$ Korczak (2014): 40. 
Służby Cywilnej $)^{48}$. Jest on za to dość często spotykany w innych systemach prawnych. Za klasyczny przykład wdrożenia tej koncepcji może uchodzić amerykański Senat, w którym reprezentanci stanowi wybierani sa na sześcioletnie kadencje, z tym że co 2 lata trzecia część składu izby ustępuje miejsca nowo wybranym członkom.

VIII. Dla kadencyjności organów władzy publicznej duże znaczenie ma zdarzenie prawne będące podstawą rozpoczęcia kadencji. W przypadku organów wybieralnych, takich jak Sejm i Senat oraz Prezydent, będą to wybory powszechne, których zarządzenie ma ogólną podstawę konstytucyjną (art. 98 ust. 2 i art. 128 ust. 2); w przypadku Trybunału Konstytucyjnego czy Trybunału Stanu będzie to wybór sędziego bądź członka przez Sejm (art. 194 ust. 1 zd. pierwsze i art. 199 ust. 1 zd. pierwsze Konstytucji) ${ }^{49}$. Z kolei czynnością kreująca na urząd Prezesa Naczelnego Sądu Administracyjnego, Rzecznika Praw Obywatelskich czy członka Krajowej Rady Radiofonii i Telewizji jest powołanie, przy czym może być w nie zaangażowanych wiele podmiotów i w różnych konfiguracjach, np. Prezydent, któremu kandydatów przedstawia Zgromadzenie Ogólne Sędziów Naczelnego Sądu Administracyjnego (art. 185 Konstytucji), Sejm działający za zgodą Senatu (art. 209 ust. 1 Konstytucji) bądź też Sejm, Senat i Prezydent realizujący swoją kompetencję łącznie, lecz niekoniecznie parytetowo, jak w przypadku Rady Polityki Pieniężnej (art. 214 ust. 1 Konstytucji).

Warto zauważyć, że moment wykonania kompetencji kreacyjnej wobec organu nie musi przesądzać początku jego kadencji. Częstokroć kwestia ta regulowana jest precyzyjnie dopiero na poziomie ustawowym ${ }^{50}$, choć Konstytucja wyraźnie stwierdza na przykład w art. 128 ust. 1, że kadencja Prezydenta rozpoczyna się w dniu objęcia przez niego urzędu, a zgodnie z ust. 2 tego artykułu wybory odbywają się zasadniczo jeszcze przed upływem kadencji dotychczaso-

${ }^{48}$ Zob. odpowiednio art. 15 ust. 4 nieobowiązującej ustawy z 29 kwietnia 1985 r. o Trybunale Konstytucyjnym (Dz. U. 1991, Nr 109, poz. 470 ze zm.); art. 21 ust. 1 ustawy z 21 listopada 2008 r. o służbie cywilnej (Dz. U. 2020, poz. 265) w brzmieniu obowiąującym przed zmianą dokonaną ustawą z 30 grudnia 2015 r. o zmianie ustawy o służbie cywilnej oraz niektórych innych ustaw (Dz. U. 2016, poz. 34).

49 Dla skuteczności wyboru sędziego TK na dziewięcioletnią kadencję prawnie irrelewantny jest natomiast akt odebrania od niego ślubowania przez Prezydenta - zob. wyrok TK z 3 grudnia 2015 r., K 34/15, OTK-A 2015, nr 11, poz. 185.

50 Dla przykładu, indywidualna kadencja członka Rady Polityki Pieniężnej rozpoczyna się nie w dniu jego powołania, lecz w dniu następującym po dniu wygaśnięcia kadencji poprzedniego członka - taki wniosek interpretacyjny płynie z art. 13 ust. 3 ustawy z 29 sierpnia 1997 r. o Narodowym Banku Polskim (Dz. U. 2019, poz. 1810). Z kolei pierwszy dzień kadencji sędziego TK tylko wyjątkowo może się pokryć z dniem jego wyboru - taka sytuacja ma miejsce wtedy, gdy mandat poprzednika wygasł jeszcze przed dniem podjęcia uchwały przez Sejm o wyborze danej osoby na to stanowisko; co do zasady bowiem Sejm dokonuje wyboru przed upływem kadencji dotychczasowego sędziego, a pierwszy dzień urzędowania nowo wybranej osoby przypada następnego dnia po upływie kadencji sędziego, którego mandat dobiega końca - zob. Zubik (2011): 102-103. Więcej problemów może sprawiać ustawodawcy ustalenie początku zbiorowej kadencji organu, zwłaszcza kiedy kompozycja jego składu odbywa się etapami, w warunkach zróżnicowanych wymogów proceduralnych lub przy udziale kilku podmiotów. Przykładowo, kadencja Krajowej Rady Radiofonii i Telewizji liczona jest od dnia powołania ostatniego członka - zob. art. 7 ust. 4 zd. pierwsze ustawy z 29 grudnia 1992 r. o radiofonii i telewizji (Dz. U. 2019, poz. 361 ze zm.). 
wego Prezydenta. Również czteroletnie kadencje Sejmu i Senatu rozpoczynaja się już po wyborach, z dniem zebrania się Sejmu na pierwsze posiedzenie i trwają do dnia poprzedzającego dzień zebrania się Sejmu następnej kadencji (art. 98 ust. 1 i 2 Konstytucji). W ten sposób Konstytucja gwarantuje nieprzerwane istnienie parlamentu i eliminuje zjawisko przerw międzykadencyjnych. W korelacji ze specyfiką zasad zarządzania wyborów do Sejmu i Senatu oraz zwoływania pierwszego posiedzenia (art. 98 ust. 2 i art. 109 ust. 2 Konstytucji) sprawia to, że określony na 4 lata czas trwania kadencji parlamentu nie ma wymiaru bezwzględnego i w rzeczywistości będzie zawsze przynajmniej o kilka dni dłuższy ${ }^{51}$.

IX. Z uwagi na dopuszczalność ponownego pełnienia funkcji przez okres kadencji wyróżnia się trzy typy kadencji: kadencję powtarzalną w sposób nieograniczony, kadencję powtarzalną w sposób ograniczony oraz kadencję niepowtarzalna ${ }^{52}$. W pierwszym przypadku kwestia powtórnego wyboru lub powołania nie jest w ogóle przedmiotem regulacji prawnej, co oznacza, że piastun organu lub członek organu kolegialnego po zakończeniu kadencji może kandydować na urząd bez względu na posiadany na tym stanowisku staż. Dotyczy to między innymi posłów i senatorów, dla których przeszkodą w ponownym uzyskaniu mandatu parlamentarnego może być ewentualnie nieuzyskanie akceptacji ze strony wyborców, utrata prawa wybieralności bądź też po prostu brak woli samego zainteresowanego.

Pozostałe typy kadencji w różnym stopniu (względnie lub bezwzględnie) ograniczają możliwość ponawiania kadencji organu wykonującego zadania publiczne. Typ drugi dopuszcza sprawowanie po raz kolejny funkcji kadencyjnej przez tę samą osobę, lecz tylko w określonym wymiarze. Przykładowo, zgodnie z art. 127 ust. 2 i art. 205 ust. 1 Konstytucji kadencje Prezydenta i Prezesa Najwyższej Izby Kontroli sa powtarzalne tylko jednokrotnie. Zupełnie wykluczona jest natomiast reelekcja po odbyciu kadencji niepowtarzalnej, która na poziomie konstytucyjnym została odniesiona wyłącznie do urzędu sędziego Trybunału Konstytucyjnego (art. 194 ust. 1 zd. drugie). Jednokadencyjność mandatu sędziego wiąże się bezpośrednio z kwestią zabezpieczenia niezależności Trybunału i niezawisłości sędziowskiej ${ }^{53}$.

X. Zasada kadencyjności jest podstawową zasadą działania władz publicznych w państwie demokratycznym. Takie założenie przyjmuje również polska Konstytucja, która w wielu swoich przepisach reguluje kwestie dotyczące kadencji poszczególnych organów. Z całokształtu przepisów konstytucyjnych określających podstawy organizacyjne organów władzy publicznej daje się wręcz wyprowadzić swoiste domniemanie o ich obligatoryjnie kadencyjnym charakterze, chyba że istnieje wyraźna podstawa do twierdzenia przeciwne-

${ }^{51}$ Garlicki (1999): 8-10. Stosunkowo podobną konstrukcję przewiduje art. 39 niemieckiej Ustawy zasadniczej, z tym że z treści ust. 1 i 2 tego artykułu wynika łącznie, że czteroletnia kadencja Bundestagu może trwać maksymalnie 2 miesiące krócej lub maksymalnie 30 dni dłużej zob. szerzej Kretschmer (2009): 32-33.

52 Korczak (2014): 41.

53 Zubik (2011): 101. 
go. Ustawodawca konstytucyjny realizuje w ten sposób jedną z kluczowych funkcji norm ustrojowych - znajdującą swój wyraz między innymi także w zasadzie podziału władzy - jaka jest powściagnie tendencji do kumulacji (monopolizacji) władzy przez jej piastunów. Kadencyjność ogranicza bowiem władzę $\mathrm{w}$ aspekcie temporalnym, zawężając zakres sprawowanych pełnomocnictw do z góry oznaczonego przedziału czasowego. Z prawnej konstrukcji kadencji wynika zarazem konieczność cyklicznego uruchamiania procedur weryfikacyjnych (w formie wyborów bezpośrednich lub pośrednich), wymuszajacych aktualizację społecznego poparcia dla osób sprawujących funkcje publiczne.

Obok rotacyjnej funkcji kadencyjności nie można tracić z pola widzenia stabilizacyjnego aspektu tej zasady. W tym sensie tworzy ona niejako stan stabilizacji personalnej danego organu w ramach kadencji, co daje mu przez ten czas określoną dozę swobody i niezależności w wykonywaniu zadań i kompetencji. Ten niewatpliwie gwarancyjny wymiar kadencyjności ma szczególne znaczenie dla tych organów, których ustrojowa pozycja w państwie opiera się na przyznaniu im odpowiednio szerokiego zakresu niezależności lub samodzielności. Konstrukcja kadencji zapewnia im wówczas zdolność do wytyczania kierunków swojego działania i realizacji przypisanych im kompetencji w sposób zasadniczo wolny od ingerencji w odrębność ich bytu ${ }^{54}$.

Dominik Eukowiak

Uniwersytet Warszawski

d.lukowiak@uw.edu.pl

https://orcid.org/0000-0002-8539-1340

Brzozowski, W. (2016). Niezależność konstytucyjnego organu państwa i jej ochrona. Warszawa.

Brzozowski, W. (2017). O potrzebie reformy konstytucyjnej. Państwo i Prawo 72(12): 3-22.

Garlicki, L. (1999). Komentarz do art. 98, uwagi 7-8, [w:] L. Garlicki (red.), Konstytucja Rzeczypospolitej Polskiej. Komentarz. Tom 1. Warszawa: 8-11.

Grajewski, K. (2009). Odpowiedzialność posłów i senatorów na tle zasady mandatu wolnego. Warszawa.

Grajewski, K. (2018). Przedterminowe zakończenie kadencji Pierwszego Prezesa Sądu Najwyższego w świetle art. $12 \S 1$ oraz art. $111 \S 1$ i 44 nowej ustawy o Sądzie Najwyższym. Gdańskie Studia Prawnicze 40(2): 609-620.

Gwiżdż, A. (1975). Organizacja i zasady funkcjonowania, [w:] A. Burda (red.), Sejm Polskiej Rzeczypospolitej Ludowej. Wrocław-Warszawa-Kraków-Gdańsk: 239-337.

Hofmann, H., Dreier, H. (1989). Repräsentation, Mehrheitsprinzip und Minderheitenschutz, [w:] H.P. Schneider, W. Zeh (Hrsg.), Parlamentsrecht und Parlamentspraxis in der Bundesrepublik Deutschland. Berlin-New York: 165-198.

Jastrzębski, J., Zubik, M. (2007). Mandat wolny versus weksel. Przegląd Sejmowy 15(2): 67-85.

Korczak, J. (2014). Kadencyjność organów jednostek samorządu terytorialnego. Samorząd Terytorialny 24(7/8): 38-50.

Kretschmer, G. (2009). Kommentar zu Art. 39, Randnummer 43-46, [w:] W. Kahl, Ch. Waldhoff, Ch. Walter (Hrsg.), Bonner Kommentar zum Grundgesetz. Ordner 10. Heidelberg: 30-33.

Ławniczak, A., Masternak-Kubiak, M. (2002). Zasada kadencyjności Sejmu - wybrane problemy. Przegląd Sejmowy 10(3): 9-26.

Łukowiak, D. (2018). Charakter prawny kadencji wybranych członków Krajowej Rady Sądownictwa (uwagi na tle wyroku Trybunału Konstytucyjnego w sprawie K 5/17). Przegląd Legislacyjny 25(2): 63-79.

${ }^{54}$ Brzozowski (2016): 186. 
Magiera, S. (2018). Kommentar zu Art. 39, Randnummer 3, [w:] M. Sachs (Hrsg.), Grundgesetz. Kommentar. München: 1253.

Morlok, M. (2015). Kommentar zu Art. 39, Randnummer 10, [w:] H. Dreier (Hrsg.), Grundgesetz. Kommentar. Band 2. Tübingen: 1138-1139.

Radajewski, M. (2018). Glosa do wyroku TK z 20.06.2017 r., K 5/17 (wybór członków Krajowej Rady Sądownictwa). Państwo i Prawo 73(3): 132-139.

Radajewski, M. (2019). Constitutional aspects of the reform of the Polish justice system in 20172018. International and Comparative Law Review 19(1): 276-293.

Schliesky, U. (2018). Kommentar zu Art. 39, Randnummer 23, [w:] P.M. Huber, A. Voßkuhle (Hrsg.), Grundgesetz. Kommentar. Band 2. München: 1102-1103.

Schneider, H.P. (1989). Kommentar zu Art. 39, Randnummer 5, [w:] R. Wassermann (Hrsg.), Kommentar zum Grundgesetz für die Bundesrepublik Deutschland. Band 2. Neuwied-Kriftel-Berlin: 64

Siemieński, F. (1980). Prawo konstytucyjne. Warszawa-Poznań.

Skrzydło, W. (1997). Konstytucyjne założenia systemu organów państwa i ich wpływ na kształt aparatu państwowego, [w:] W. Skrzydło (red.), Ustrój i struktura aparatu państwowego i samorządu terytorialnego. Warszawa: 7-34.

Versteyl, L.-A. (1989). Beginn und Ende der Wahlperiode, Erwerb und Verlust des Mandats, [w:] H.P. Schneider, W. Zeh (Hrsg.), Parlamentsrecht und Parlamentspraxis in der Bundesrepublik Deutschland. Berlin-New York: 467-488.

Zubik, M. (2005). Powoływanie członków Rady Polityki Pieniężnej w świetle zasady kadencyjności oraz działalności organów państwa. Przegląd Sejmowy 13(4): 37-52.

Zubik, M. (2010). Organy centralnego banku państwa między legalizmem a koniecznościa, [w:] M. Modrzejewska (red.), Prawo handlowe XXI wieku. Czas stabilizacji, ewolucji czy rewolucji. Księga jubileuszowa Profesora Józefa Okolskiego. Warszawa: 1419-1428.

Zubik, M. (2011). Status prawny sędziego Trybunału Konstytucyjnego. Warszawa.

Zubik, M. (2018). Między profesjonalizmem a głosowaniem większości w demokratycznym państwie prawa. Zeszyty Naukowe Sądownictwa Administracyjnego 14(5): 65-74.

\section{THE CONSTITUTIONAL FRAMEWORK OF THE TERM OF OFFICE OF PUBLIC AUTHORITIES}

Summary

The paper focuses on the issue of the term of office, recognized as the foundation of the functioning of public authorities in a democratic state. The starting point for more detailed considerations is the recognition that the content of the term of office consists of two basic elements - the temporal one, determining the maximum period during which a supervisor or a member of the body can perform a public function, and the stabilizing one, which ensures there is minimal staff turnover during the term of office. From the entirety of the provisions of the Constitution creating the organizational framework of constitutional bodies of public authority, the author derives the thesis on the obligatory nature of the term of office of each body, unless there is a clear legal basis justifying the opposite. However, this does not mean that the constitutional regulations regarding the term of office of individual bodies are shaped according to a uniform pattern. On the contrary, different types of the term of office can be distinguished on the basis of the Constitution. Analysing particular models of the term of office, the author gives practical examples of normative solutions and indicates the consequences resulting from their application. The conclusion presents the view that the term of office is a constitutional structure guaranteeing the authorities a certain latitude or independence in the process of realizing their legal competences.

Keywords: principle of the term of office; public authorities; term of the body; composition of the body; Constitution 